Robert Wolny

University of Economics in Katowice, Poland

\title{
THE DEVELOPMENT OF PROSUMPTION ON THE POLISH E-SERVICES MARKET
}

In the information age, the growth of prosumer behavior would not be possible without the development of ICT technologies. The interactivity of contemporary media creates favourable conditions for the development of prosumption (a combination of "production" and "consumption.") The article presents the problem of the behaviors of e-service consumers and demonstrates the results of a qualitative study which was conducted in 2018. For the purpose of the study, non-participant observation was adopted: conversations on internet forums dedicated to e-services were followed.

Key words: prosumption, prosumer, e-services, ICT, non-participant observation JEL Codes: M31, L86

\section{Introduction}

Technological development, in particular, the revolution in information technology (IT), has changed the way society and the economy function, and has impacted the functioning of the service market. One symptom of the new economic reality and of virtualization is the emergence of the e-service market. The changes in consumer interest in e-services are the result of changes in consumer attitudes to Internet networks and various ICT technologies. In recent years, the Internet, various mobile devices and online applications have significantly impacted the behaviour of market entities. The service sector has seen dynamic development of ICT, and the level of modernization in ICT determines the level of modernity for the whole economy.

The popularization of ICT technologies (mainly in the service sector) has significantly influenced consumer behaviour, bringing changes not only to the place of purchase but also to the subject and frequency of purchase, information gathered and many other issues. The shift of consumer behaviour to e-behaviour ${ }^{1}$ is also a step towards prosumption.

The aim of the article is to identify and exemplify prosumer behaviour for consumers on the e-service market and also to present a new product solution for this market.

\section{Development of prosumption}

Although the term prosumption is a coinage of the words production and consumption, its etymology has not been clearly defined. The phenomenon of prosumption is described as a mixture of consumption and production processes until the distinctions between them become less clear ${ }^{2}$. According to Guido and Peluso ${ }^{3}$, Alvin Toffler, who introduced the

\footnotetext{
${ }^{1}$ M. Jaciow, R. Wolny: Polski e-konsument. Typologia, zachowania, OnePress, Gliwice 2011, p. 10.

${ }^{2}$ B. Jung B: Kapitalizm postmodernistyczny. „Ekonomista” 1997, nr 5-6, p. 720.
} 
term in his book "The Third Wave" in 1980, is known as the precursor of prosumption. Prosumption might be the effect of the following tendency: consumption is involved in the production process - the producer becomes a consumer, so production is involved in consumption - the consumer becomes a producer. Prosumption might also be described as a desire to possess products which are in accordance with consumer conceptions. Thanks to individual choices and activities, consumers become co-producers of a given product ${ }^{4}$. Toffler $^{5}$ describes situations which indicate that consumers are taking over some functions which were previously attributed to producers; for instance:

- Consumers are focused on: purchasing new products and exchanging broken/ damaged items for new ones; using the scope of available services in order to perform all the activities pertaining to restoration, servicing and storage of the purchased products on their own; performing (on their own) a greater number of services which had been previously performed outside the household;

- Consumers consciously become involved in the process of design and preparation of goods and services, which makes them become creative consumers.

The determinants of the development of prosumption might be divided into two categories. The first distinguishes so-called general determinants (biological, economic, social, cultural and technological factors) which are connected with consumption as it is more broadly understood. These determinants also influence prosumption (a particular example of consumption). The second category distinguishes the factors which are specific to prosumption ${ }^{6}$, which are:

- The increase of free time and the need to fulfil it in an attractive way;

- The possibility of working from home and combining it with consumption activities;

- The development of education;

- Changes in the work culture and redefining the role of labour in human life: the evolution of labour towards creativity.

Other factors which are involved in the development of prosumption include: economic and social trends, technological development, knowledge and research development, and the activities of companies (Figure 1).

For Toffler, the main source of prosumption was a developing self-help movement (emergence of organizations and consumer societies whose main aim was providing help by exchanging experiences, observations and advice) and the involvement of consumers in dealing with issues which were previously performed by companies, e.g. through the growth of self-service activities in the process of customer service or involving consumers in the process of product design ${ }^{7}$. It must be stressed that ICT development contributes to the development of prosumption and an increase in the number of

\footnotetext{
${ }^{3}$ G. Guido, A. M. Peluso: Preconditions for the diffusion of prosumption among firms: a case study approach. „Problems and Perspectives in Management” 2008, Vol. 6, Issue 4, p. 65.

${ }^{4}$ D. Gach: Pozyskiwanie i wykorzystywanie wiedzy klientów. „E-Mentor” 2008, nr 23, p. 57.

${ }^{5}$ A. Toffler: Trzecia fala. PIW, Warszawa 1997, p. 79.

${ }^{6}$ Cz. Bywalec, L. Rudnicki: Konsumpcja, PWE, Warszawa 2002, p. 145.

${ }^{7}$ Toffler A., 1997. Trzecia fala. PIW Warszawa, p 420.
} 
prosumers. It is even believed that each Internet user is a prosumer, although not every prosumer is a user of the network ${ }^{8}$.

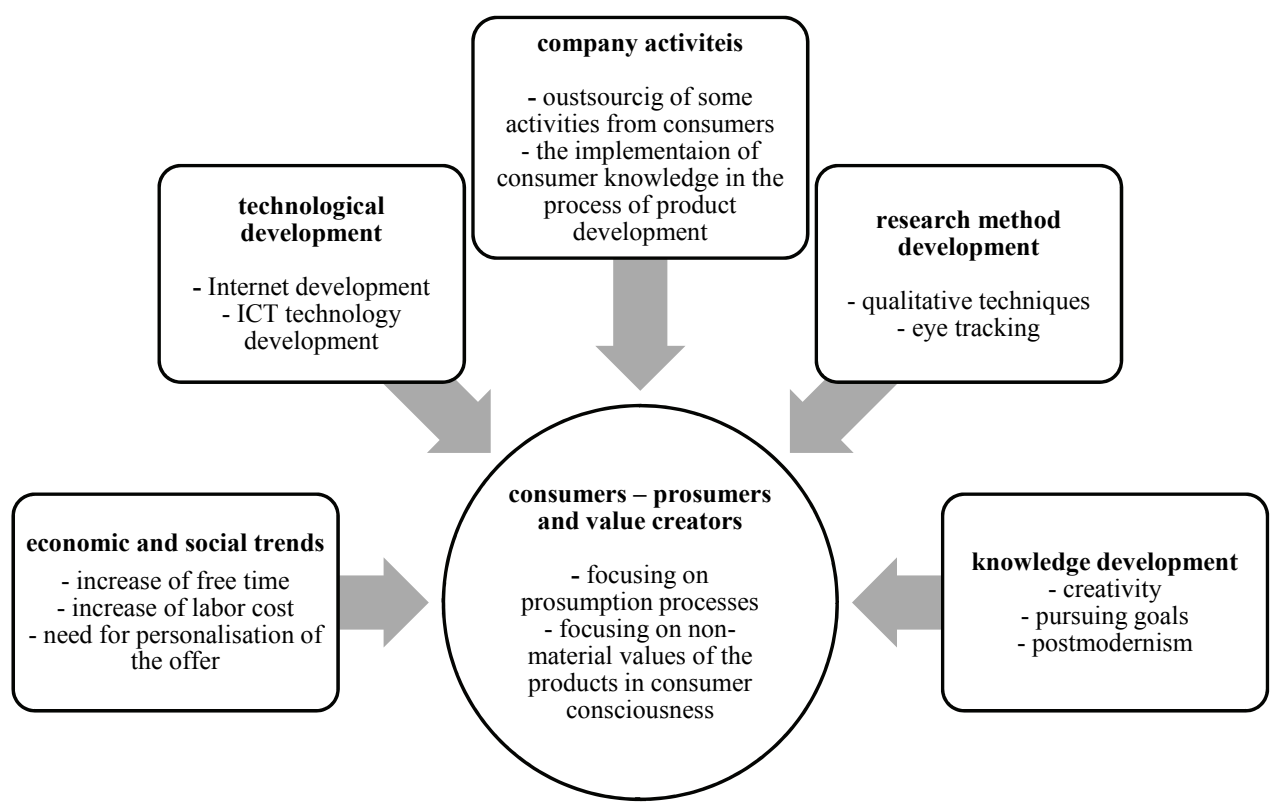

Figure 1. Factors which allow the development of prosumption

Source: Author's study based on: S. V. Troye, Ch. Xie: The active consumer: Conceptual, methodological, and managerial challenges of prosumption. Norwegian School of Economics and Business Administration, 2007, p. 16.

A prosumer might also be called a person who describes or comments on products (brands) on internet websites, while sharing at the same time his/her knowledge and remarks not only with other consumers, but producers as well ${ }^{9}$. There are a vast number of places on the Internet in which prosumer behaviour can be observed (these are places where prosumers are able to put their comments or opinions about products and/or exchange their opinions with other prosumers). Such places include: vertical portals (vortals), corporate portals, social networking websites, blogs and internet forums ${ }^{10}$. Social networking websites and internet forums are places which are most popular among prosumers.

Prosumers' level of involvement in the information transfer varies. Some prosumers merely express their opinion about the product (they recommend it or not to others). However, there are some active prosumers who try to participate in designing or improving the service offer. Figure 2 presents the stages of development of prosumer behaviours on the e-service market.

8 I. A. Baruk, A. Iwanicka: Prosumpcja internetowa vs. Prosumpcja pozainternetowa. Prace Naukowe Uniwersytetu Ekonomicznego we Wrocławiu 2016, nr 459, p. 184.

${ }^{9}$ K. Domańska: Kim jest prosument. „Marketing w praktyce” 2009, nr 29, p. 37.

${ }^{10}$ M. Bartosik-Purgat: Social networking sites as a channel for delivering information about durable products and its impact on purchasing decisions. "Acta Scientiarum Polonorum Oeconomia" 2018, nr 17 (1), p. 8; R. Wolny: Prosumpcja i prosument na rynku e-usług. „Konsumpcja i Rozwój” 2013, nr 1(4), p. 156. 


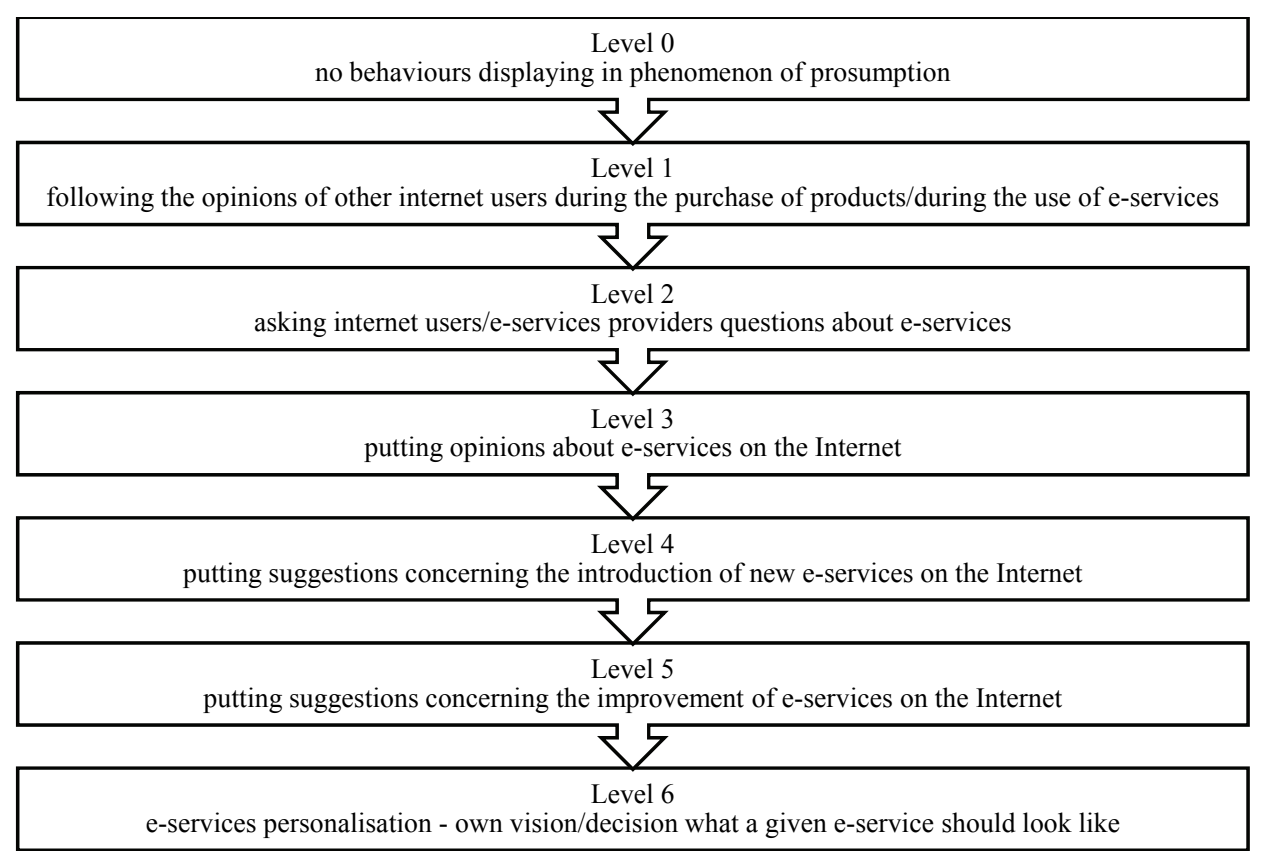

Figure 2. Stages of development of prosumer behaviours on the e-service market Source: Author's own elaboration.

According to $\mathrm{Xie}^{11}$, the theory of prosumption is connected with a new form of interaction between a producer and consumer, which follows the concept of DIY (do it yourself). Toffler observed that the production of standard goods filled the market. That is why, in order to continue production growth, companies need to initiate the process of customization of mass production into very personalized products. Reaching a high level of adjusting products to consumer needs requires involving consumers - prosumers - in the production process, especially at the level of establishing design requirements. To conclude, it might be stated that prosumer behaviours are the element of broadly understood economic behaviours of individuals ${ }^{12}$, which include:

- Real processes - the aim of which is expending workload, financial and material resources,

- Information processes - the aim of which is transferring data, opinions, comments and decisions (nowadays, consumer opinion transfer is recognized as part of the concept of consumer involvement ${ }^{13}$ ).

\footnotetext{
${ }^{11} \mathrm{Ch}$. Xie: Trying to prosume. Toward a perspective on prosumption, Norwegian School of Economics and Business Administration, 2008, p. 2.

${ }^{12}$ Z. Kędzior: Zachowania gospodarstw domowych i przedsiębiorstw. Prawidłowości, determinanty. CBiE AE Katowice, Katowice 1997, p. 20.

${ }^{13}$ M. Kucia: Studium terminologiczne koncepcji Costumer engagement, „Handel Wewnętrzny” 2018, nr 6 (377) tom II, p. 240.
} 


\section{Source material and research methods}

The implementation of participant and non-participant observation in the research of prosumption on the e-service market provides reliable results ${ }^{14}$. The use of observation for the purpose of Internet research means learning and observing the behaviours of people and phenomena and their effects performed on the Internet. The researcher provides intentional remarks according to a previously established plan. The research is conducted in accordance with the procedures of netnography research and follows five steps (Figure 3).

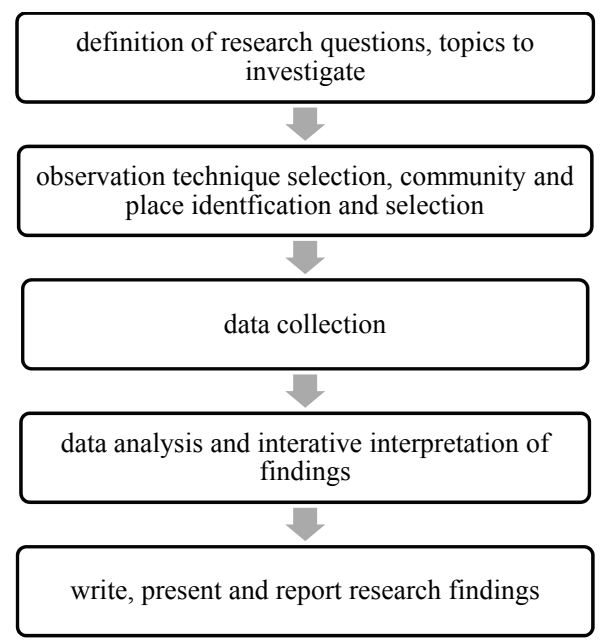

Figure. 3. Simplified model of netnography research project

Source: R. V. Kozinets: Etnografia. Badania etnograficzne online. Wydawnictwo Naukowe PWN, Warszawa 2012

According to Wolny ${ }^{15}$, non-participant observation on the Internet involves using the information which already exists in the network (the so-called archive materials from internet forums) and drawing certain conclusions. The main aim of non-participant observation is to diagnose situations - the frequency and course of action of certain phenomena - yet it does not analyse the reasons for these phenomena. Elements of the content analysis of texts which are put on internet forums are used in the research of eservice markets in order to assess: assortment in the offer of e-services, prices of eservices, purchase and prosumer behaviour of consumers. Content analysis also focuses on the language, style and symbols incorporated in the researched texts. It might be stated that content analysis resembles an inventory, as the means in which the information is collected from primary sources and the unfeasibility of repetition of the conditions in which the data is gathered. This makes all the information unique, and the

\footnotetext{
${ }^{14}$ A. Dąbrowska, M. Janoś-Kresło, A. Wódkowski: E-usługi a społeczeństwo informacyjne. Difin, Warszawa 2009, p. 124; D. Silverman: Prowadzenie badań jakościowych. Wydawnictwo Naukowe PWN, Warszawa 2008, p. 82; P. Baines, B. Chansarkar: Introducing Marketing Research. Wiley, New York 2002.

${ }^{15}$ R. Wolny: Możliwości wykorzystania obserwacji w Internecie w badaniach rynku e-usług. Prace Naukowe Uniwersytetu Ekonomicznego we Wrocławiu 2014, nr 336, p. 353.
} 
informative value of such data is significant. Finally, as far as the research of the market of e-services is concerned, there is no alternative way, so far, of data collection.

The article demonstrates the results of the primary research of 146 internet forums dedicated to the market of e-services. For the purpose of the research, non-participant observation was implemented. The observation covered the period from January 2017 to June 2018. The qualitative data obtained during the research was compiled in 2018 . The total number of internet users of the researched forums was 51154 (46.6\% men and 36.1 $\%$ women). It was not possible to identify the sex of $17 \%$ of the participants - neither upon the users' nickname, nor the user's style. The most significant number of participants (17333) expressed their comments on forums dedicated to e-banking, whereas the lowest number of participants (4208) expressed their comments on forums dedicated to e-administration. The total number of posts which were put online during the period of 18 months was 54473 . The largest number is represented by posts on ebanking internet forums (19 132); the lowest on e-administration forums (4872). Table 1 presents basic characteristics of the researched forums.

Table 1. Basic characteristics of the researched forums

\begin{tabular}{|c|c|c|c|c|c|c|}
\hline \multirow{2}{*}{ Type } & \multirow{2}{*}{$\begin{array}{l}\text { Number of } \\
\text { internet forums }\end{array}$} & \multicolumn{4}{|c|}{ Participants of internet forums } & \multirow{2}{*}{$\begin{array}{l}\text { Number of } \\
\text { posts }\end{array}$} \\
\hline & & Total & women & men & $\begin{array}{c}\text { Sex } \\
\text { unidentified }\end{array}$ & \\
\hline e-banking & 30 & 17333 & 4952 & 8985 & 3396 & 19132 \\
\hline e-culture & 30 & 13455 & 6952 & 5128 & 1375 & 15225 \\
\hline e-education & 30 & 9206 & 5268 & 1968 & 1970 & 9886 \\
\hline e-insurance & 28 & 4952 & 1374 & 2852 & 726 & 5358 \\
\hline e-administration & 28 & 4208 & 1255 & 2068 & 885 & 4872 \\
\hline total & 146 & 51154 & 18477 & 23825 & 8852 & 54473 \\
\hline
\end{tabular}

Source: Author's own research.

\section{Results and discussion}

The implementation of non-participant observation resulted in the identification of consumer behaviour at levels 3,4 and 5 (see Figure 2). The results clearly show that internet users demonstrate willingness to share both positive and negative opinions about given phenomena. Positive opinions were mostly expressed by e-consumers on the internet forums dedicated to e-education, e-culture and e-administration, whereas ebanking and e-insurance forums were dominated by negative opinions (Table 2).

Table 2. Opinions about e-services on internet forums (in \%)

\begin{tabular}{|l|c|c|c|}
\hline Type of e-service & negative & Opinions & positive \\
e-banking & 57,8 & neutral & 35,6 \\
e-culture & 33,7 & 6,7 & 64,6 \\
e-education & 18,9 & 1,7 & 71,6 \\
e-insurance & 57,3 & 9,5 & 35,2 \\
e-administration & 36,8 & 7,5 & 59,2 \\
\hline
\end{tabular}

Source: Author's own research. 
The observation of prosumer behaviour on levels 4 and 5 resulted in gathering valuable information concerning the introduction of new e-services and improvement of the currently functioning services.

E-banking services are very popular e-services in Poland and the number of users is constantly growing. In 2018, 44\% of Poles used e-banking services, which was below the EU average of $50 \%{ }^{16}$. The results clearly indicate that the level of prosumer behaviour of the consumers of e-banking is significantly higher than the level of consumers of other financial services ${ }^{17}$. Men were significantly more active on ebanking internet forums than women (8985 men and 4952 women expressed their opinions on the 30 researched forums). Internet users who participated in online discussions very often pointed out certain modifications of the services or suggested introducing new e-services which are provided by other institutions. The participants suggested a set of new e-services which should be implemented by e-banking; for instance: facilitating the use of bank accounts, banking applications and foreign currency accounts, connecting e-banking services with other services and introducing new solutions in the field of money transfer and e-banking security.

The participants also suggested a set of improvements for the current e-services. These improvements usually referred to the interface of bank websites (including mobile applications), expansion of the scope of services and modification of helpdesk services (Table 3).

Table 3. Suggestions concerning the improvement of e-banking services - selected examples

\begin{tabular}{|c|c|}
\hline $\begin{array}{l}\text { Introduction } \\
\text { of new e- } \\
\text { services }\end{array}$ & $\begin{array}{l}\text { - Introduction of mobile account for Windows Phone } \\
\text { - Introduction of new option "remember the receiver for future transactions" } \\
\text { - Introduction of the possibility of sending email transfer confirmation } \\
\text { - } \quad \text { Introduction of ready-to-fill ZUS transfers } \\
\text { - The possibility of using QR code while signing a transfer } \\
\text { - Introduction of online banking advisor } \\
\text { - Introduction of online foreign currency account in \$CAD (Canadian dollars) } \\
\text { - Introduction of anonymous bank accounts } \\
\text { - Introduction of access to other public services with the use of e-banking } \\
\text { - Introduction of e-loans }\end{array}$ \\
\hline $\begin{array}{l}\text { Modification } \\
\text { of current e- } \\
\text { services }\end{array}$ & $\begin{array}{l}\text { - Improvement of the bank's website } \\
\text { - } \quad \text { The use of BLIK in the case of using other bank's cash deposit machine } \\
\text { - } \\
\text { - } \\
\text { - } \\
\text { - } \\
\text { - } \\
\text { - } \\
\text { - } \\
\text { - } \\
\text { - } \\
\text { - } \\
\text { - }\end{array}$ \\
\hline
\end{tabular}

Source: Author's own research.

\footnotetext{
${ }^{16}$ Społeczeństwo informacyjne w Polsce 2018. Wyniki badań statystycznych z lat 2014-2018. GUS Warszawa Szczecin (www.stat.gov.pl).

${ }^{17}$ E. Kieżel, S. Smyczek: Model zachowań prosumenckich konsumentów na rynku usług finansowych. „Konsumpcja i Rozwój” 2013, nr 2(5), p. 102.
} 
E-culture services integrate ICT with the process of production, distribution, presentation, preservation and (second) use of the works of culture ${ }^{18}$. One of the characteristic features of e-culture services is the fact that they might be sold online, provided in a traditional form (ticket sales) or provided exclusively online (e.g. access to e-books, virtual visit to a museum $)^{19}$. Women were shown to be more active on e-culture forums than men (6952 women and 5128 men expressed their opinions on the 30 researched forums). As far as new e-services are concerned, the users suggested the possibility of publishing their own output, the introduction of new solutions to ticket sales and access to Internet films. Modifications in the area of e-culture services mainly concerned quality improvements of films, $\mathrm{mp} 3 \mathrm{~s}$, e-books, website and mobile application interfaces. Also, the participants suggested improvements of certain e-culture services in order to adjust them to disabled users (Table 4).

Table 4. Suggestions concerning the improvement of e-culture services - selected examples

\begin{tabular}{|c|c|}
\hline $\begin{array}{l}\text { Introduction } \\
\text { of new e- } \\
\text { services }\end{array}$ & $\begin{array}{ll}\text { - } & \text { Introduction of new film categories } \\
\text { - } & \text { Introduction of ticket sales on social websites } \\
\text { - } & \text { Possibility of publishing drawings, pictures and graphics made by amateur artists } \\
\text { - } & \text { Possibility of adding own films } \\
\text { - } & \text { Introduction of online chat } \\
\text { - } & \text { Introduction of single fee for films - instead of subscriptions } \\
\text { - } & \text { Introduction of one-day access to e-books } \\
\text { - } & \text { Introduction of film database connected with music database } \\
\text { - } & \text { Introduction of multi-language speech recognition device } \\
\text { - } & \text { Possibility of getting in touch with the seller through social networks }\end{array}$ \\
\hline $\begin{array}{l}\text { Modification } \\
\text { of current e- } \\
\text { services }\end{array}$ & 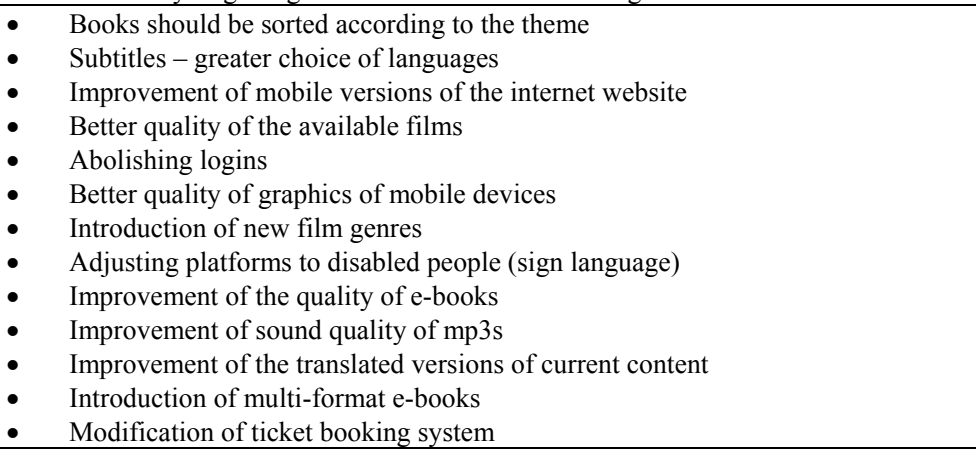 \\
\hline
\end{tabular}

Source: Author's own research.

In 2018 11,4\% of Poles used the Internet for education purposes ${ }^{20}$. E-education services are becoming more popular, as they help their users save time (e.g. commuting), require smaller financial outlays and are not limited geographically. Women were significantly more active on e-education forums than men (5268 women and 1968 men

\footnotetext{
${ }^{18}$ A. Dąbrowska, M. Janoś-Kresło, A. Wódkowski: E-usługi a społeczeństwo informacyjne. Difin, Warszawa 2009, p. 86.

${ }^{19}$ R. Wolny: Rynek e-usług w Polsce - funkcjonowanie i kierunki rozwoju. UE, Katowice 2013, p. 18.

${ }^{20}$ Społeczeństwo informacyjne w Polsce 2018. Wyniki badań statystycznych z lat 2014-2018. GUS Warszawa Szczecin (www.stat.gov.pl).
} 
expressed their opinions on the 30 researched forums). The users suggested a number of new e-services, namely: introduction of audio and video e-services, introduction of new methods of teaching with the use of available technologies, and the possibility of taking online examinations. As far as modifications of e-education services are concerned, the participants focused on: technical issues of websites and mobile applications, class schedule (it should be changed), teaching methods and, finally, class evaluation process (Table 5).

Table 5. Suggestions concerning the improvement of e-education services - selected examples

\begin{tabular}{|c|c|}
\hline $\begin{array}{l}\text { Introduction } \\
\text { of new e- } \\
\text { services }\end{array}$ & $\begin{array}{ll}\text { - } & \text { Introduction of online examinations } \\
\text { - } & \text { Introduction of audio lectures } \\
\text { - } & \text { Introduction of courses for foreigners } \\
\text { - } & \text { Introduction of video courses } \\
\text { - } & \text { Introduction of platforms allowing learning through various instant messengers } \\
\text { - } & \text { Introduction of conversations with native speakers } \\
\text { - } & \text { Introduction of e-services on various platforms (Smart TV, VR goggle) } \\
\text { - } & \text { Introduction of new teaching methods (through music, games, etc.) } \\
\text { - } & \text { Courses with the use of internet cameras - it would allow eye contact with the teacher } \\
\text { - } & \text { Implementation of latest teaching methods (e.g. online tests, infographics, etc.) } \\
\text { - } & \text { Introduction of e-consultants (or another form of contact in case of problems) } \\
\text { - } & \text { Introduction of online courses in pairs }\end{array}$ \\
\hline $\begin{array}{l}\text { Modification } \\
\text { of current e- } \\
\text { services }\end{array}$ & 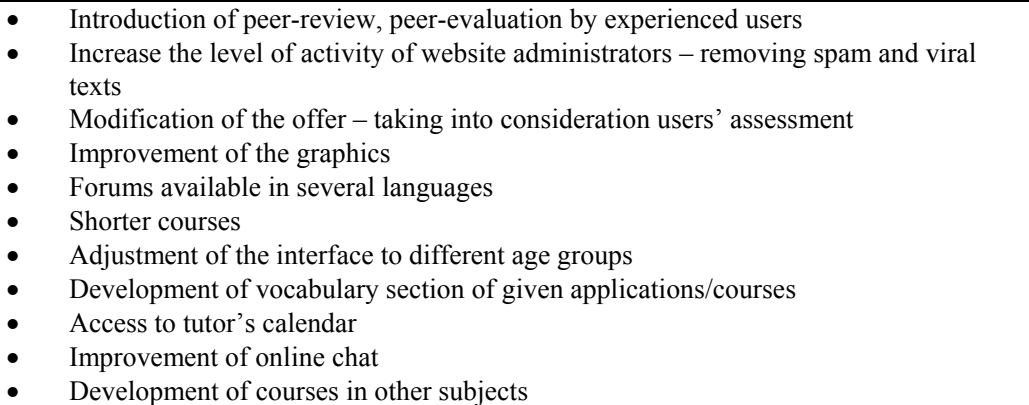 \\
\hline
\end{tabular}

Source: Author's own research.

E-insurance services is an umbrella term for the following online services which refer to the insurance market: offering, negotiating, concluding contracts and loss adjustment. Although the distribution model of insurance services is dominated by agents, the share of its virtual channel is significantly increasing ${ }^{21}$. As far as the study is concerned, men were more active than women on e-insurance forums (2852 men and 1374 women). The participants of the research suggested new solutions to e-insurance services; among them, the most popular were: new possibilities of taking out insurance, introduction of insurance for particular age groups and against particular risks. The modification suggested by the participants referred to the improvement of communication and simplification of taking out insurance (Table 6).

${ }^{21}$ P. Pliszka: E-ubezpieczenia w polskim społeczeństwie informacyjnym. „Studia Informatica Pomerania” 2017, nr 4(46), p. 75. 
Table 6. Suggestions concerning the improvement of e-insurance services - selected examples

\begin{tabular}{|c|c|}
\hline $\begin{array}{l}\text { Introduction } \\
\text { of new e- } \\
\text { services }\end{array}$ & $\begin{array}{ll}\text { - } & \text { Introduction of downloadable forms } \\
\text { - } & \text { Introduction of price comparison system } \\
\text { - } & \text { Introduction of wider offers for people over } 60 \\
\text { - } & \text { Introduction of new, personalized e-insurance offers } \\
\text { Introduction of e-insurance offers for different sports }\end{array}$ \\
\hline $\begin{array}{l}\text { Modification } \\
\text { of current e- } \\
\text { services }\end{array}$ & $\begin{array}{ll}\text { - } & \text { Shortening waiting time (online replies concerning compensation or repair) } \\
\text { - } & \text { Modification of the preliminary forms } \\
\text { - } & \text { Employing more staff } \\
\text { - } & \text { Modification and simplification of online contracts } \\
\text { - } & \text { Improvement of offer comparison system } \\
\text { - } & \text { Improvement of helpdesk } \\
\text { - Improvement of skype communication }\end{array}$ \\
\hline
\end{tabular}

Source: Author's own research.

In 2018, 35,5\% of Poles used e-administration services ${ }^{22}$. The main aim of using eadministration services was to search information on public administration websites, download different forms, and finally send different forms and applications (growing popularity of online tax returns). The results of the study indicate that men were more active on e-administration internet forums than women. Approximately, 2068 men and 1255 women expressed their opinions on the 28 researched forums (Table 7).

Table 7. Suggestions concerning the improvement of e-insurance services - selected examples

\begin{tabular}{|c|c|}
\hline $\begin{array}{l}\text { Introduction } \\
\text { of new e- } \\
\text { services }\end{array}$ & $\begin{array}{l}\text { - Introduction of the obligation of use of electronic mail boxes by public administration } \\
\text { offices (e.g. NFZ, ZUS) } \\
\text { - } \quad \text { Introduction of the following online services: child birth registration, new-born } \\
\text { benefit, day care centre application, kindergarten application, school application } \\
\text { - } \quad \text { Introduction of online deletion of an unemployed person from the registration system } \\
\text { - } \quad \text { Introduction of e-mail reminder of the validity of certain documents (introduction of } \\
\text { the possibility of online registration of a public benefit organization) } \\
\text { - } \quad \text { Introduction of e-administration spots in shopping malls } \\
\text { - } \quad \text { Introduction of one consolidated e-service platform } \\
\text { - } \quad \text { Introduction of local platforms } \\
\end{array}$ \\
\hline $\begin{array}{l}\text { Modification } \\
\text { of current e- } \\
\text { services }\end{array}$ & 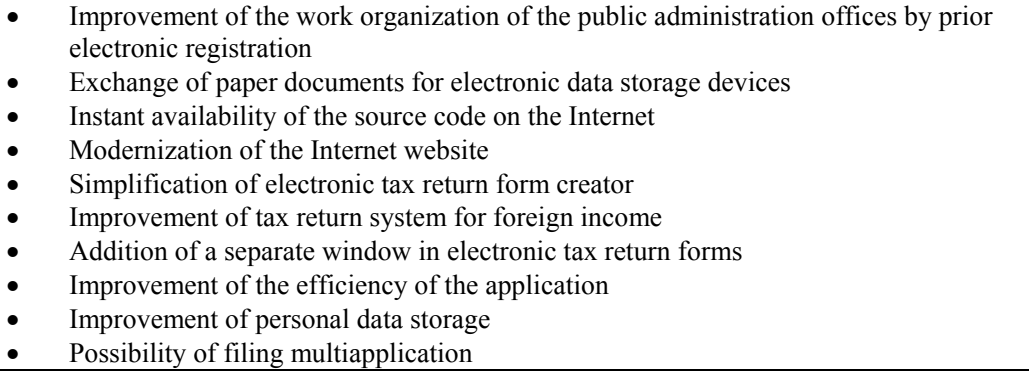 \\
\hline
\end{tabular}

Source: Author's own research.

${ }^{22}$ Społeczeństwo informacyjne w Polsce 2018. Wyniki badań statystycznych z lat 2014-2018. GUS Warszawa Szczecin (www.stat.gov.pl). 
The participants suggested the introduction of new e-services for people with children, new possibilities of self-service and the possibility of consolidation of eservices. The suggestions concerning the modification of e-services included: technical issues of the public administration websites, form filing procedures and improvement of security.

\section{Conclusions}

The virtualization of services might contribute to the development of the e-service market in two ways: first, the introduction of e-services attracts new consumers; second, the e-service environment creates favourable conditions for the development of prosumption. The prosumption of e-services allows further development and improvement of the services, which might also result in attracting new consumers. A prosumer is more than just a consumer. It is a person who possesses broad knowledge of e-services and demonstrates this knowledge to others, especially in decision-making processes. Prosumers want to participate in creating the offer of products and services. Technological progress and the development of ICT technologies have significantly influenced the development of prosumption and online prosumption. It might be expected that in future the phenomenon of e-service co-creation and active participation in designing individualized e-services will grow. Such phenomenon might be perceived as the highest form of prosumption.

The presented research results indicate that consumers on the e-services market are active prosumers. Consumers engage in internet forums dedicated to the market of eservices. Prosumer behaviors identified in the research process are associated with putting opinions about e-services (level 3) and putting suggestions concerning the improvement of e-services or in the introduction of new e-services on the Internet (levels 4 and 5).

Undoubtedly, new e-services which were suggested by internet users are not revolutionary; however, the implementation of selected solutions might be appreciated by the users and will broaden the scope of e-services. As far as participation in different forms of prosumer behaviours is concerned, it might be concluded that prosumption is developing; thus, one might expect significant growth of the phenomenon in future.

\section{Bibliography}

Baines P., Chansarkar B.: Introducing Marketing Research, Wiley, New York 2002

Bartosik-Purgat M.: Social networking sites as a channel for delivering information about durable products and its impact on purchasing decisions, Acta Scientiarum Polonorum Oeconomia, $17(1) / 2018$

Baruk I. A., Iwanicka A.: Prosumpcja internetowa vs. Prosumpcja pozainternetowa, Prace Naukowe Uniwersytetu Ekonomicznego we Wrocławiu, 459/2016

Bywalec Cz., Rudnicki L.: Konsumpcja, PWE, Warszawa 2002

Dąbrowska A., Janoś-Kresło M., Wódkowski A.: E-usługi a społeczeństwo informacyjne, Difin Warszawa 2009

Domańska K.: Kim jest prosument, Marketing w praktyce, 29/2009

Gach D.: Pozyskiwanie i wykorzystywanie wiedzy klientów, E-Mentor, 23/2008

Guido G., Peluso A. M.: Preconditions for the diffusion of prosumption among firms: a case study approach, Problems and Perspectives in Management. Vol. 6, Issue 4/2008 
Jaciow M., Wolny R.: Polski e-konsument. Typologia, zachowania, OnePress, Gliwice 2011

Jung B.: Kapitalizm postmodernistyczny, Ekonomista, 5-6/1997

Kędzior Z.: Zachowania gospodarstw domowych i przedsiębiorstw. Prawidłowości, determinanty, CBiE AE Katowice, Katowice 1997

Kieżel E, Smyczek S.: Model zachowań prosumenckich konsumentów na rynku ustug finansowych, Konsumpcja i Rozwój, 2(5)/2013

Kozinets R. V.: Etnografia. Badania etnograficzne online, Wydawnictwo Naukowe PWN Warszawa 2012

Kucia M.: Studium terminologiczne koncepcji Costumer engagement, Handel Wewnętrzny, 6 $(377) / 2018$

Pliszka P.: E-ubezpieczenia $w$ polskim społeczeństwie informacyjnym, Studia Informatica Pomerania, 4(46)/2017

Silverman D.: Prowadzenie badań jakościowych, Wydawnictwo Naukowe PWN, Warszawa 2008 Społeczeństwo informacyjne w Polsce 2018. Wyniki badań statystycznych z lat 2014-2018, GUS Warszawa Szczecin (www.stat.gov.pl).

Toffler A.: Trzecia fala, PIW, Warszawa 1997

Troye S. V., Xie Ch.,: The active consumer: Conceptual, methodological, and managerial challenges of prosumption, Norwegian School of Economics and Business Administration, 2007

Wolny R.: Możliwości wykorzystania obserwacji w Internecie w badaniach rynku e-ustug, Prace Naukowe Uniwersytetu Ekonomicznego we Wrocławiu, 336/2014

Wolny R.: Prosumpcja i prosument na rynku e-ustug, Konsumpcja i Rozwój, 1(4)/2013

Wolny R., Rynek e-ustug $w$ Polsce - funkcjonowanie i kierunki rozwoju, UE, Katowice 2013

Xie Ch.: Trying to prosume. Toward a perspective on prosumption, Norwegian School of Economics and Business Administration, 2008

\section{Rozwój prosumpcji na rynku E-usług w Polsce}

\section{Streszczenie}

W dobie społeczeństwa informacyjnego wzrost zachowań prosumenckich nie byłby możliwy bez rozwoju technologii ICT. Interaktywność współczesnych mediów sprzyja rozwojowi zjawiska prosumpcji. Artykuł przedstawia zagadnienia związane z postępowaniem nabywców e-usług i prezentuje wyniki badań jakościowych. Badania przeprowadzono techniką obserwacji nieuczestniczącej w 2018 roku śledząc uczestników dyskusji na branżowych forach internetowych poświęconych e-usługom. Artykuł ma charakter badawczy.

Słowa kluczowe: prosumpcja, prosument, e-usługi, ICT, obserwacja nieuczestnicząca.

Jel Code: M31, L86

Information about author:

dr hab. Robert Wolny, prof. UE

University of Economics in Katowice

Faculty of Economics

Department of Markets and Consumption

40-287 Katowice

ul. 1 Maja 50

e-mail: robert.wolny@ue.katowice.pl

ORCID: 0000-0003-4088-718X 